\title{
NATO-EU COOPERATION ON C4ISR CAPABILITIES FOR CRISIS MANAGEMENT
}

\author{
Amleto GABELLONE
}

\begin{abstract}
This paper addresses enabling solutions to enhance the NATO and EU cooperation facing the new emergency threats that characterize current crisis scenarios. Military and civilian actors are required to work together and cooperate in Crisis Management, using state-of-the-art capabilities for solving societal crises in order to prevent the escalation to conflict and to avoid or alleviate the consequences of natural or man-made disasters. However, technical shortfalls and political issues still hamper the integration and cost-effectiveness use of NATO and EU capabilities. The NEC/Web-2 concept can enable interoperability between NATO and EU; military support of C4ISR capabilities to civilian authorities cooperating in both civil emergencies and crisis management could be the key driver to overcome the political issues that still undermine NATO and EU cooperation and therefore a pragmatic approach to pooling and sharing of capabilities, thus preventing duplication of efforts. Following the principles of C4ISR Comprehensive Approach, this article highlights the initiative of NC3A - the NEC architect for NATO - to support multi-national and interagency interoperability for civil-military cooperation in coordination with NATO OPS Division and relevant EU and international governmental and non-governmental bodies involved in Crisis Management/Civil Emergency operations. It also outlines enabling cooperation areas such as Science and Technology, regional cooperation and joint exercises in crisis management.
\end{abstract}

Keywords: Crisis Management, Civil Emergencies, Comprehensive Approach, NATO-EU Cooperation, C4ISR capabilities, NC3A, Civil-Military Interoperability, Defence Support to Civilian Authorities.

\section{Introduction}

The world around NATO and EU has changed over the past two decades. International 'Crisis Management' (CM) is today the key concept of NATO and EU defence and security policy and strategy, almost entirely replacing the concept of 'deterrence' that addressed past cold-war scenarios of a bipolar world. 
The new security environment is unpredictable and rapidly evolving. New threats originate from weak states, asymmetric conflicts, organized crime, cyber attacks, WMD, energy and climate challenges, natural or man-made catastrophes. These new security challenges push NATO and EU countries to re-evaluate the word crises and $\mathrm{CM}$, originally considered as the short phase between the end of an almost stable period of peace and war, as a permanent 'therapy' (conflict or disaster prevention) that needs to start very long before reaching the 'critical' stage, where overcoming the turning point is never likely to happen. ${ }^{1}$

Today multi-dimensional and 'quantum style' security threats demand therefore a comprehensive response— $\mathrm{a}$ 'Comprehensive Approach' (CA)—in which civilian and military crisis management activities need to be coordinated. This CM coordination is at all levels: civil-civil (e.g. diplomats, aid workers and policemen), military-military (different contributing countries), but more and more at civil-military level, both for civilian support to military in the field (CIMIC/CMCO) and in particular for military support to civilian actors (designated also as DSCA - Defence Support to Civilian Authorities) during a disaster relief mission. ${ }^{2}$

The lesson learned from NATO operations, in particular in Afghanistan and Western Balkans, makes clear that a comprehensive political, civilian and military approach is necessary for effective crisis management. The Alliance will engage actively with other international actors before, during and after crises to encourage collaborative analysis, planning and conduct of activities on the ground, in order to maximize coherence and effectiveness of the overall international effort. ${ }^{3}$

As the Comprehensive Approach aims to bring together different actors around a common management of complex crises, it poses the question of the links between international organizations when they intervene on a common territory, such as in the Afghanistan war (where NATO, UN and EU are present together) or in the Haiti earthquake crisis (where several governmental and non-governmental organisations contributed together with UN and various military capability support). ${ }^{4}$

Specific NATO and EU CA issues in crisis management derive from the two organizations' potential complementarity. This complementarity is due to a large shared membership (21 common members), a shared strategic vision, overlapping operational ambitions and policy initiatives in the capability development field (i.e. NRF and EU Battle-groups) and the need to make best use of decreasing resources and avoid duplication of efforts. ${ }^{5}$

Probably the main issue is that NATO is a military Alliance mainly based on article 5 and therefore the EU, holding civilian crisis management capabilities already institutionalized with the organization, should play the role which NATO cannot fulfil in CM scenarios. This is true in theory but practice shows a different situation. Even 
though-according the Council of the EU-the EU Battle-groups' full operational capability was achieved in early $2007,{ }^{6}$ many questions remain on their limited degree of interoperability and effectiveness of dealing with high risk and complex crisis situations. The EU Military Staff is working hard on interoperability plans covering the shortfalls identified by the EDA Capability Development Plan (CDP), but many capability gaps remain. The implementation of such plan will remain a long-term objective. $^{7}$

From the other side, one of NATO's main difficulties is the fact that the Alliance internally does not fully benefit from deployable civilian capabilities and integrating civilian aspects into military ones seems going beyond its mandate. Some common NATO and EU member allies push for a clearer and shared role between the two organizations, due also to financial problems related to CA by NATO (e.g. the reconstruction activities in Afghanistan).

It is clear that today many crises and conflicts require use of civilian capabilities of crisis management and a combination of diplomatic, economic and social instruments for which NATO is not fully equipped. The EU could be able to develop such a comprehensive policy where use of military capabilities is based on the principles of human security, protection of civilians and unbiased contribution. Therefore one realistic solution in facing complex crisis scenarios is the enhancement of EU C4ISR capabilities (in order to fulfill the interoperability shortfalls) through a stronger and pragmatic cooperation with NATO. ${ }^{8}$

\section{Theory and Practice of NATO-EU Cooperation}

The NATO-EU cooperation on security and defence is one of the relevant issues of the new NATO Strategic Concept:

An active and effective European Union contributes to the overall security of the EuroAtlantic area. Therefore the EU is a unique and essential partner for NATO. The two organisations share a majority of members, and all members of both organisations share common values. NATO recognizes the importance of a stronger and more capable European defence. We welcome the entry into force of the Lisbon Treaty, which provides a framework for strengthening the EU's capacities to address common security challenges. Non-EU Allies make a significant contribution to these efforts. For the strategic partnership between NATO and the EU, their fullest involvement in these efforts is essential. NATO and the EU can and should play complementary and mutually reinforcing roles in supporting international peace and security. We are determined to make our contribution to create more favourable circumstances through which we will:

- fully strengthen the strategic partnership with the EU, in the spirit of full mutual openness, transparency, complementarity and respect for the autonomy and institutional integrity of both organisations; 
- $\quad$ enhance our practical cooperation in operations throughout the crisis spectrum, from coordinated planning to mutual support in the field;

- broaden our political consultations to include all issues of common concern, in order to share assessments and perspectives;

- $\quad$ cooperate more fully in capability development, to minimise duplication and maximise cost-effectiveness. ${ }^{9}$

The European Union also addressed the need of a stronger partnership with NATO in a spirit of mutual reinforcement and respect for their decision making autonomy. The European Council noted the NATO's statement in the Strasbourg-Kehl Summit declaration concerning the importance of a stronger and more capable European defence and welcoming the EU's efforts to strengthen its capabilities and its capacity to address common security challenges. The Council particularly stressed the importance of efficient operational cooperation between the EU and NATO, in particular concerning theatres in which both organizations are committed. The Council also reiterated the necessity to continue to further exploit the approved framework for association of non-EU European Allies with the ESDP, in accordance with EU procedures. ${ }^{10}$

Both NATO and EU have logically identified similar shortfalls in military capabilities that limit the deployability and sustainability of respective Crisis Management assets in spite of their huge overall numbers. Therefore, various initiatives have been launched to enhance capability development. Today formal coordination on capability development takes place in the NATO-EU Capability Group. ${ }^{11}$ Membership of the group comprises NATO and non-NATO EU Members that have security agreement with NATO. NATO is typically represented by DPP (Defence and Policy Planning) and DI (Defence Investment) Divisions of the International Staff and defence representatives and advisors from the missions and capitals. EU is usually represented by Permanent Representations' counsellors to the Political-Military Group, the EDA PP (Policy and Plan) unit and the CMPD (Crisis Management and Planning Directorate). ${ }^{12}$

Despite proven shared capability requirements, the work of NATO-EU CG is weakened by political problem similar to those encountered at PSC (EU Political and Security Committee) and NAC (NATO North Atlantic Council) level. Membership in NATO and EU does not overlap completely, there is lack of a security agreement between NATO and EDA and absence of an arrangement with Turkey. The main issue is that Member States still make decisions on national defence planning with little or no reference to either NATO or the EU, whose guidelines are often trumped by considerations of prestige, national defence industry and budget. The result is a very fragmented effort. As Nations insist on remaining active in a wide range of capability areas, in spite of the decreasing size of armed forces and defence budgets, a plethora of small-scale capabilities, of limited deployability and low cost-effectiveness, is 
scattered across Europe. The strategic enablers required to achieve the transformation to expeditionary operations and civil-military assets in order to face complex crisis missions are being developed very slowly. At the same time, massive duplications and redundancies are maintained in areas of limited usefulness, huge cuts in national defence budgets up to 25 percent done with no coordination with the other allies may lead to a sum total of European capabilities that is even less coherent and employable than is the case today. ${ }^{13}$

\section{NATO and EU Civil Military Capabilities in Crisis Management}

After assessing the importance of the NATO and EU relationships, which highlighted common shortfalls and issues that impede an authentic strategic association between the two organizations and a realist cooperation in capability development, it is essential to analyze how to increase and deepen the strategic collaboration in Crisis Management and Civil Emergencies in order to ensure a practical and effective coordination in the scenarios in which both NATO and EU are requested to intervene. It seems logical that if NATO tends to implement the comprehensive approach as the remedy or general solution in crisis management, the definition of security adopted by NATO must be in line with that approach. This broad concept of security will obviously imply the need to act through civilian capacities, and not solely through military force. ${ }^{14}$

Since the 2006 Riga Summit, NATO enhanced its Crisis Management capacity to support stabilization and reconstruction efforts during a complex crisis through the Civil Emergency Planning (CEP). The new Civil Military Planning and Support Section under the Planning Directorate of the Operations Division covers specific areas in which civil support may be required for "non-article 5" missions or Crisis Response Operations (CRO). This support is provided through a range of civilian capabilities (NATO ad hoc staff and a civil experts network) and instruments (the Civil Capabilities Catalogue and the Rapid Reaction Team, for CIMIC/CMCO purposes, and the Euro-Atlantic Disaster Response Coordination Centre for DSCA purposes), under the overall guidance of the Senior Civil Emergency Planning Committee (SCEPS). The Euro-Atlantic Disaster Response Coordination Centre (EADRCC) is therefore the main NATO instrument in support to civilian authorities in Crisis Management. The EADRCC activities are closely coordinated with other international organizations, such as the United Nations Office for the Coordination of Humanitarian Assistance (UN-OCHA), the International Atomic Energy Agency (IAEA), the World Health Organization (WHO) and the EU. ${ }^{15}$ An example of a useful capability is the military satellite picture shown in Figure 1.

Crisis Management in the European Union is a capacity under the European External Action Service (EEAS) - the EU body created after the Lisbon Treaty to support the 


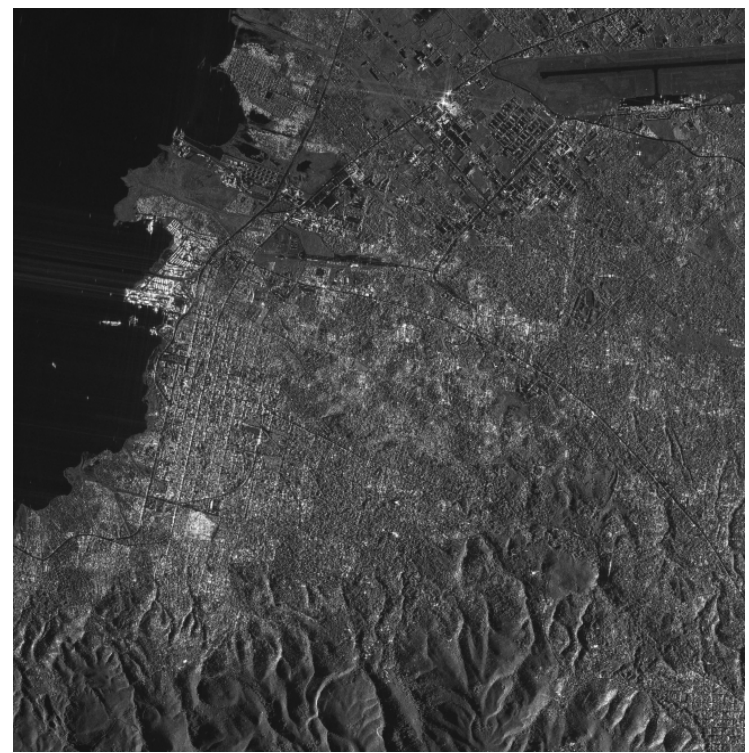

Figure 1: Haiti SAR Satellite Image on 14 January 2010

(by Italian Defence COSMO-SkyMed system).

High Representative of the Union for Foreign Affairs and Security Policy. The Instrument for Stability (IfS) and the EU Battle-groups are the EU means to provide a response to potential conflict situation, crisis response, conflict prevention and peace building in short time. A complex crisis, such as a man-made or natural disaster, is managed under the EU Civil Protection Mechanism that since the beginning of 2010 has been part of the European Commission ECHO (Humanitarian Aid Department). The Community Mechanism for Civil Protection has a number of tools intended to facilitate adequate preparedness, as well as effective response to disasters at a community level.

The Monitoring and Information Centre (MIC) is the operational heart of the Mechanism (Figure 2 shows a satellite picture provided by EU MIC). It is operated by DG Environment of the European Commission and accessible all the time. It gives countries access to a platform collecting all civil protection means available among participating states. The Common Emergency and Information System (CECIS) is a reliable web-based alert and notification application created with the intention of facilitating emergency communication. It is normally a civilian topic which pertains to EU members, but which can also involve the European Commission via instruments like the Stability Instrument or DG ECHO. The possibility of having military assistance for disaster relief at the request of the MIC was recently developed. In consultation 


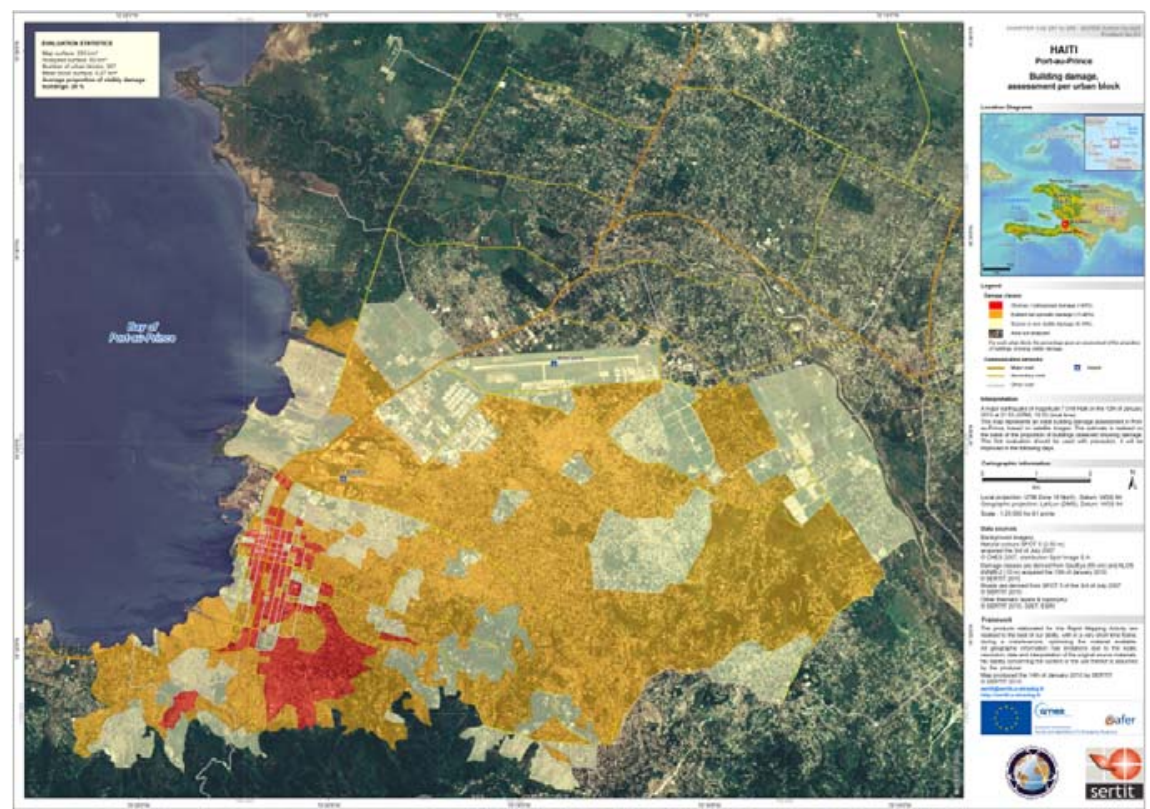

Figure 2: Haiti’s Map of Building Damage (by European Union/SERTIT/GMES).

with the Commission, the EU Military Staff (EUMS) is responsible for pre-identifying capabilities and generic force packages. A Crisis Steering Group has been established, consisting of the EU Presidency, Commission, Council Secretariat and concerned member states. ${ }^{16}$

\section{Enabling C4ISR Capabilities for Civil-Military Cooperation in Crisis Management}

C4ISR (Command, Control, Communications, Computers, Intelligence, Surveillance, and Reconnaissance) is more and more considered as a glue for operations and transformation under the framework of NATO Network Enabled Capabilities (NNEC) vision based on 'Interoperability in Secure Environment.' The spectrum of possible C4ISR capabilities to support Civil Authorities in Crisis Management is wide, most of the relevant capabilities being dual-use and allowing a high level of interoperability. The C4ISR Comprehensive Approach is a key concept to contribute to NATO success, including through closer cooperation with partners - nations and organizations (EU in the first place). ${ }^{17}$ 
Discussions of NEC concepts focus almost exclusively on the post-crisis phases of the conflict spectrum. But Crisis Management is a relevant area where NEC concepts and improved interoperability could play a critical role. A non-traditional or emergent threat, which is trans-national and asymmetric in nature, demands new ways of fostering rapid and coordinated crisis responses by both civilian and military actors. C4ISR capabilities and methodologies offer tools to help predict early signs of an emerging crisis. Information and Communication Technologies (ICT) can be exploited to rapidly form crisis action teams providing seamless access to relevant data and shared consultations. Information assurance techniques help the protection of certain sensitive categories of information from cyber attacks.

As explained above, civil-military cooperation in crisis management is not always possible or wanted by all players. Divergences on perspectives, missions and goals as well as cultural, social and political differences make cooperation between military and some civil organizations very difficult to achieve. Each organization normally develops its own ICT solutions to support crisis and emergency response. However, this normally results in a lack of interoperability and coordination not only between organizations, but even within the organization itself. Therefore, technical-operational information sharing and interoperability solutions could be important enablers to improve coordination.

The NATO Consultation, Command and Control Agency (NC3A) has launched a multi-national initiative aiming to complement the efforts of NATO, national and international organizations (e.g. Strategic Commands, CIMIC Centre of Excellence and civil-military Coordination Offices for humanitarian assistance) in the DOTMLPF ${ }^{18}$ approach by providing a full NEC/Web-2 capability architecture (DOTMLPFI + Interoperability) addressing the principles of Federations and Service Oriented Architecture (SOA). ${ }^{19}$

The goal of the Multi National CIvil-Military InterOPerability initiative (MN CMIOP) is to improve civil-military interaction and provide comprehensive solutions to Nations through establishing a collaborative civil-military environment-a forum-where the most critical problems are identified and analyzed, and solutions are explored, specified and validated (see Figure 3). NC3A has extensive experience in supporting NATO efforts in Crisis Response Operations and in complex C4ISR interoperability endeavours. Interoperability is addressed at three levels:

- Technical, including the specification of interfaces and profiles for services, protocols and data to be used by each of the participating systems, as much as possible, by adopting, tailoring and completing (if required) available international or de-facto standards; 

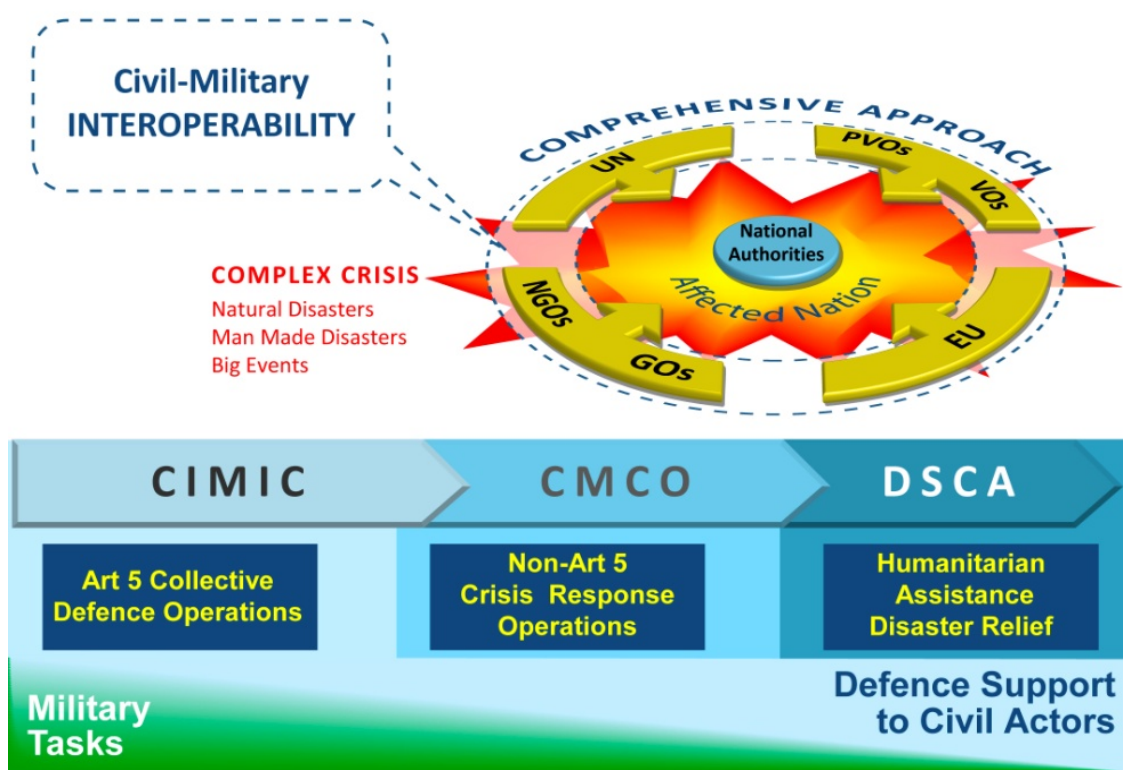

Figure 3: NC3A Civil-Military Interoperability Initiative in support of Complex Crisis Management.

- Operational, including the development and demonstration of concepts of employment and the Standard Operating Procedures (SOP) required for the operational implementation of the technical solutions;

- Architectural, including the design of patterns for the implementation of the technical solutions with the participating systems in various employment scenarios.

Interoperability Focus Areas (IFA), based on specific Interoperability Enablers, are identified (Figure 4) and selected to support the core stages (in bold) of the crisis/ emergency management phases: Vulnerability Analysis, Mitigation and Prevention, Preparedness and Planning, Prediction and Warning, Response, Recovery and Stabilization (see Figure 5).

On 14 June 2011 NC3A hosted the $1^{\text {st }}$ Workshop on Multinational Civil-Military Interoperability Cooperation, supported by NATO OPS Division/Planning Directorate and aiming to leverage common interests and national activities from a coalition of willing Nations and Organizations to: 


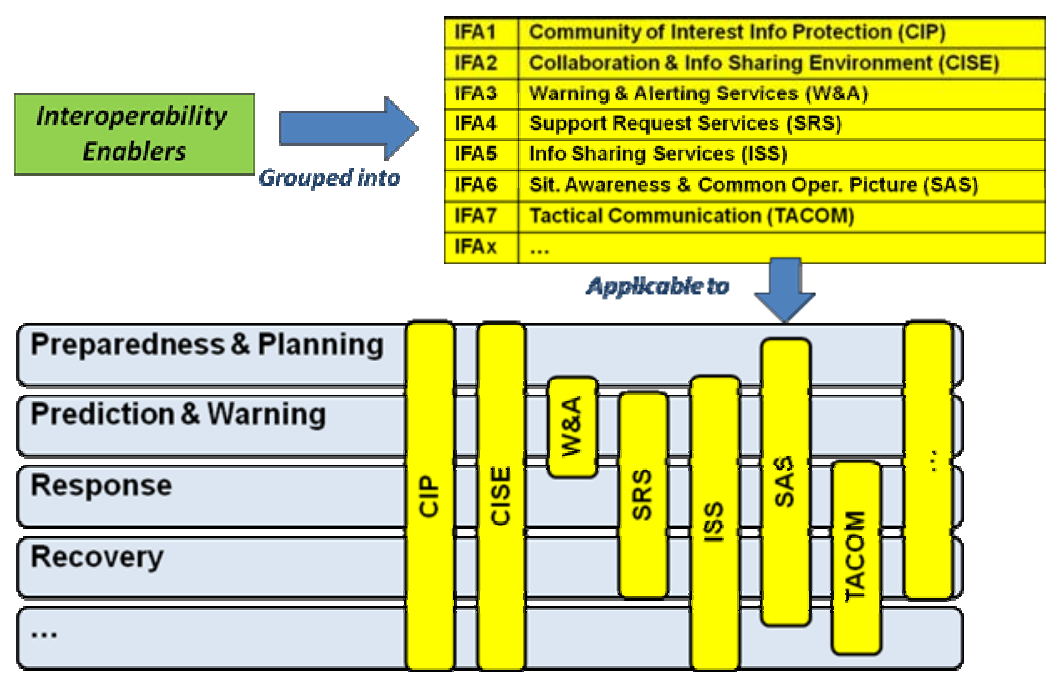

Figure 4: Interoperability Focus Areas (IFAs).

- Communicate and Inform within and across Communities of Interest (CoI), in order to enable the visibility and exchange of information between civil and military bodies, nodes and systems, maximizing the quality of information while assuring trust and protection and avoid duplications;

- Communicate with and in the theatre, in order to implement solutions to facilitate interoperability between the deployed units;

- Share the same Situation Picture, by implementing standard interfaces to support the exchange of tactical situation data and real-time collaboration;

- Disseminate and get prompt warnings on emergencies in order to create a federated Emergency Warning and Alerting Services among all the civil and military entities (services and system) involved and the affected population;

- Enhance decision-making processes by improving and harmonizing the sources of information and empowering correlation capabilities within each actor;

- Improve Situational Awareness and Coordination by enabling the sharing and automated collection of relevant data from the different information system of civil or military organizations;

- Improve the quality of the support to Training and Exercises (live and/or computer-aided) by enhancing the interoperability of the involved systems. 


\begin{tabular}{|l|l|l|}
\hline \multicolumn{1}{|c|}{ Phase } & Coordination activities & Interoperability enablers \\
\hline $\begin{array}{l}\text { Preparedness \& } \\
\text { Planning }\end{array}$ & $\begin{array}{l}\text { Joint Training and Exercises } \\
\text { Contingency planning } \\
\text { Develop/ Capabilities }\end{array}$ & $\begin{array}{l}\text { Capability R\&D \& validation } \\
\text { Train\&Exer (live \& simulated) } \\
\text { Remote Collaboration }\end{array}$ \\
\hline Prediction \& Warning & $\begin{array}{l}\text { Warning \& Alerts dissem. } \\
\text { Pre-alloc of capabilities } \\
\text { Request/Offer of Support } \\
\text { Operational planning } \\
\text { Tactical planning }\end{array}$ & $\begin{array}{l}\text { Protected federated Col's. } \\
\text { Collaboration Environment } \\
\text { Alert \& Warning Service } \\
\text { Request Support Service } \\
\text { Shared capability info }\end{array}$ \\
\hline Response & $\begin{array}{l}\text { Logistics Coordination } \\
\text { Tactical Coordination } \\
\text { Joint Execution }\end{array}$ & $\begin{array}{l}\text { Logistic info exchange } \\
\text { Sit.Awareness for First Resp. } \\
\text { Common Operational Picture }\end{array}$ \\
\hline Recovery & $\ldots$ & $\ldots$ \\
\hline Stabilization & $\ldots$ & $\ldots$ \\
\hline
\end{tabular}

Figure 5: Emergency Management Phases, Coordination Activities and Interoperability Enablers.

Thirty three participants from 13 different Nations attended the workshop. Also, representatives from NATO HQ, ACT, EUMS and EDA, MN CIMIC Group and KFOR, CIMIC/C2/CSW Centres of Excellence, the Bulgarian Centre for National Security and Defence Research, the Italian Civil Protection Department, TNO, FMV, the High Institute Mario Boella of Turin, University of Genoa and Technologies Sans Frontiers NGO attended the workshop, providing a wide-angle and diverse perception of the topic.

The workshop highlighted that there are a number of initiatives that are complementary (and not overlapping) with the NC3A initiative and that could contribute to pursue interoperability also achieving an economy of scale. Within NATO, particularly relevant is the ACT Program of work on ECECI (Enterprise Collaboration Environment for Civil-military Interoperability). Other relevant initiatives are the study on Civil-Military Interoperability on ISR recently started by NIAG and the work started in 2011 by NC3A (under ACT sponsorship and NATO HQ coordination) to analyze the Civil Interface in the area of Ballistic Passive Defence (Consequences of Intercept). NC3A is involved at various degrees in all of them.

On 21-22 November a second workshop on multinational cooperation in Civil-Military Interoperability has been co-hosted by the Ministry of Defence of Bulgaria in Sofia where NC3A, supported by NATO ESC Division, proposed some C4ISR interoperability solutions that could be adopted by Nations to enable Civil-Military coop- 
eration in civil emergencies. Moreover, participating companies and research institutions presented some commercial and NATO off-the-shelf solutions, demonstrating the technology readiness levels and maturity of current capabilities and their potential implementation by international, governmental and non-governmental organizations. Both workshops' reports and presentations are available at the NC3A website. ${ }^{20}$

\section{Further NATO-EU Cooperation Areas in support of Crisis Management}

Another area where NATO and EU could join forces to enhance cooperation and avoid duplications is the use of respective defence/security Science and Technology programmes for Crisis Management. Both the EU and NATO have dedicated S\&T institutions - the EU's Joint Research Centres ${ }^{21}$ and NATO's Research and Technology Organization - and their research platforms: the ongoing EU Seventh Framework Research Programme (FP7) and NATO Science for Peace and Security Programme (SPS). Strategic goals of the Framework Programme for Research and Technological Development are strengthening the scientific and technological base of European industry and encouraging its international competitiveness, while promoting research that supports EU policies. The Science for Peace and Security (SPS) Programme is a policy tool that enhances cooperation and dialogue between NATO and its partners. It is based on security-related civil science and technology and helps to contribute towards the Alliance's core goals, aiming to promote regional cooperation through scientific projects and activities. The SPS programme consists of NATO-funded activities, as well as nationally-funded SPS activities. Some of NATO SPS and EU FP7 platform's activities directly address Crisis Management, such as SPS's defence-related environmental issues, environmental security, eco-terrorism countermeasures, disaster forecast and prevention of natural catastrophes and 4th call FP7-SEC-2011-1 on Increasing the Security of the Citizens; additional S\&T efforts in C4ISR could provide further capability development. ${ }^{22}$

Moreover Civil-Military cooperation and interoperability could be deepened through existing regional military cooperation arrangements, such as the Southern European Defence Ministerial (SEDM) ${ }^{23}$ SEDM's primary tasks are consolidation of peace and stability in the Balkans, creation of cohesive, viable, and effective regional defencemilitary forum, and provision of a credible regional voice in the international community. The activities undertaken within the SEDM are developed to strengthen the civil-military cooperation and to enhance stability and security in the South-East European region. The most significant SEDM initiative is the establishment of the SEE Brigade (SEEBRIG) that consists of a land force acting in an on-call basis for Peace Support Operations (PSO) and Disaster Relief Operations (DRO).

Finally, NATO and EU should stimulate mutual learning. Exchange of lesson learned and best practice are powerful instruments to advance defence/security capabilities in 
Crisis Management. Use of open web-based information clearing-house mechanisms could be established, as addressed by the NC3A Multi National CMIOP initiative and ACT ECECI project, to exchange information. Workshop participation should be opened to both organizations, enhancing transparency while respecting respective roles and policies.

Joint exercises are also key enablers for C4ISR interoperability and capability enhancement. SEESIM and X24 Europe ${ }^{24}$ are very good examples of joint exercises dealing on Crisis Management. SEESIM (South-Eastern Europe SIMulation network) is US initiative under the SEDM process (began in 2000 with US funding) aiming to foster civil-military cooperation, coordination, and interoperability within the region, to promote stability and security in the region and in Afghanistan and Iraq and to address counter proliferation of WMD. SEESIM 12 will take place in October 2012 and will be hosted by Bulgaria; its scenario will be based on terrorist and cyber attacks and other man-made and/or natural disasters.

\section{Conclusion}

Having analyzed the new emergency security challenges and 'quantum style' security threats of the post 9/11 period, the Crisis Management concept that is taking over the deterrence concept of the post cold-war era, the importance of Comprehensive Approach for Crisis Management missions, the emerging concept of military support to civilian authorities involved in complex man-made or natural disasters and the importance of a C4ISR interoperability between NATO and EU capabilities, some conclusions and recommendations can be drawn up.

First of all, there is the need of a clear distribution of burdens and responsibilities, and the complementarity between NATO and the EU through harmonization of respective capabilities and a reconciliation of their level of ambition. For crisis management operations requiring civilian capacities, NATO could rely on the EU applying a sort of "Berlin Plus in reverse" concept. Similarly, if additional civilian crisis management resources are needed, NATO could support other EU capabilities, such as the EU MIC, or enhance the cooperation through the European Defence Agency through implementation of real joint initiatives. ${ }^{25}$

The working of the NATO-EU Capability Group should be optimized with a view on improving interaction and transparency between the two organizations, addressing pragmatic and short-term results focusing on "single-capability" meetings. More staff-to-staff technical contacts and participation in joint initiatives could solve most of the political problems curbing the NATO-EU cooperation.

The NC3A Multi National initiative on civil-military interoperability can facilitate the above solutions and enhance the common NATO and EU capability's coherency, 
putting together on the same table the different actors which are called to intervene in crisis management scenarios and need to cooperate and share common C4ISR capabilities.

Joint exercises are also key enablers for C4ISR interoperability and capability enhancement and can stimulate inter-governmental cross-cooperation and Civil Protection Centres in sharing responsibilities and responding to emergencies.

Further steps in NATO and EU cooperation in Crisis Management are pragmatic shared activities between the European Defence Agency (EDA) and NATO procurement agencies, such as NC3A and NAMSA. Finally the Europe's Galileo satellite navigation network project could provide a complementary support to defence networks in real-time ISR for Crisis Management.

\section{Notes:}

1 Michael Rühle, “Crisis Management in NATO,” European Security 2:4 (Winter 1993): 491501; Daniel Keohane, “The EU and NATO’s Future,” EU CSDP Newsletter 11 (Winter 2010/2011): 26-27.

2 Jean-Luc Marret, “Civil-Military Relations in Disaster Response,” in Humanitarian Assistance: Improving U.S.-European Cooperation, ed. Julia Steets and Daniel S. Hamilton (Baltimore, MD: Center for Transatlantic Relations, The Johns Hopkins University/ Global Public Policy Institute, 2009), 339-357; Cornelius Adebahr, “The Comprehensive Approach to Crisis Management in a Concerted Weimar Effort,” Genshagener Papiere 6 (Genshagen, Germany: Stiftung Genshagen, March 2011).

3 Active Engagement, Modern Defence, Strategic Concept for the Defence and Security of the Members of the North Atlantic Treaty Organisation, adopted by Heads of State and Government in Lisbon, 19 November 2010, <www.nato.int/lisbon2010/strategic-concept-2010eng.pdf $>$.

4 Headquarters Supreme Allied Commander Transformation, Study on Nations' Approaches to Comprehensive Approach, IMS no. I11002261 (April 2011).

5 Gabriella Ingerstad with Paul Sturm, EU-NATO: Assets and Interoperability, Conference Report (Brussels: ISIS Europe and the Geneva Centre for the Democratic Control of Armed Forces, April 2010), <www.isis-europe.eu/sites/default/files/events-downloads/2010_escg_ 33_conference_report_eu-nato_assets_and_interoperability.pdf $>$. 
${ }^{6}$ Council of the European Union, “Editorial," European Security and Defence Policy Newsletter no. 3 (January 2007), p. 3, <www.consilium.europa.eu/uedocs/cmsUpload/ ESDP_3_final.pdf $>$.

7 Johann Herz, "Military Capabilities: A Step Forward in ESDP," European Security Review no. 46 (October 2009), <http://www.isis-europe.org/pdf/2009_artrel_322_esr46-militarycapabilities.pdf $>$.

${ }^{8}$ Sven Biscop, Nicole Gnesotto, Jolyon Howorth, Daniel Keohane, Stefano Silvestri, and Teija Tiilikainen, What do Europeans Want from NATO?, ISS Report no. 8 (Brussels: European Union Institute for Security Studies, November 2010), <www.iss.europa.eu/ publications/detail/article/what-do-europeans-want-from-nato>.

${ }^{9}$ Active Engagement, Modern Defence, art. 32.

${ }^{10}$ General Secretariat of the Council, European Council 16 September 2010 Conclusions, CO EUR 16, CONCL 3, <www.europarl.europa.eu/meetdocs/2009_2014/documents/dplc/dv/ 3_council_16sept2010_3_council_16sept2010_en.pdf>.

${ }^{11}$ They meet approximately every 4 to 6 weeks alternating between NATO HQ and EU Council Justus Lipsius in Brussels.

${ }^{12}$ Paul Sturm, "NATO and the EU: Cooperation?," European Security Review 48 (Brussels: ISIS Europe, February 2010), <http://www.isis-europe.eu/sites/default/files/programmesdownloads/2010_artrel_445_eu-nato-capabilities.pdf >.

${ }^{13}$ Brooke Smith-Windsor, NATO's Effect Based and Comprehensive Approach to Operations - making sense of the past and future prospects, Research Paper no. 38 (Rome: NATO Defence College, July 2008), <www.isn.ethz.ch/isn/Digital-Library/Publications/ Detail/?ots591=0c54e3b3-1e9c-be1e-2c24-a6a8c7060233\&lng=en\&id=92060>; Biscop, et. al., What do Europeans Want from NATO?

${ }^{14}$ Anna Locher, "Finland: Crisis Management and Territorial Defence," CSS Analysis in Security Policy 68 (Zurich: Center for Security Studies, February 2010), $<$ www.isn.ethz.ch/isn/Digital-Library/Policy-Briefs/Detail/?lng=en\&id=113107>.

${ }^{15}$ NATO Backgrounder, Civil Support for Military Operations and Emergency Responses, NATO Press Office (January 2008), <www.nato.int/docu/cep/cep2008-e.pdf>.

16 “European Civil Protection: How Does It Relate to Humanitarian Aid?” Voice News (Brussels: Fundation Universitaire, May 2011).

${ }^{17}$ Velizar Shalamanov, MN Projects Governance Model - Driver for Change in C4ISR Pillar of NATO and Nations (Brussels: NC3A, 2010).

${ }^{18}$ Doctrine, Organization, Training, Materiel, Leadership, Personnel, Facilities.

${ }^{19}$ NC3A, Outline Report of the 1st Multi National Civil-Military Interoperability Workshop, Brussels, NATO C3 Agency, 14 June 2011; Heiko Borchert and Karina Forster, EU and NATO Must Work Together to Guarantee Energy Infrastructure Security and to Define the Role of Soft vs. Hard Power (Brussels: Security Europe, March 2007), <www.seceur.info>; Kristalina Georgieva, European Commissioner for International Cooperation, Humanitarian Aid and Crisis Response, The Humanitarian and the Military: Different Mandates and Potential Synergies, Speech/10/461. Brussels Defence Debate, Royal Military Academy, 17 September 2010; Cecile Wendling, The Comprehensive Approach to Civil-Military Crisis Management: A Critical Analysis and Perspective, IRSEM report (Paris, January 2010), $<$ www.humansecuritygateway.com/documents/IRSEM_TheComprehensiveApproachtoCivil MilitaryCrisisManagement.pdf $>$.

${ }^{20}$ www.nc3a.nato.int. 
${ }^{21}$ The organization structure is currently based on the following specialized Institutes under the Directorate General in Belgium: Geel, Belgium, The Institute for Reference Materials and Measurements (IRMM) in Karlsruhe, Germany, The Institute for Transuranium Elements (ITU) in Ispra, Italy, The Institute for the Protection and the Security of the Citizen (IPSC), The Institute for Environment and Sustainability (IES) and The Institute for Health and Consumer Protection (IHCP) - Petten, Netherlands, The Institute for Energy (IE) Sevilla, Spain, The Institute for Prospective Technological Studies (IPTS).

22 Borchert and Forster, EU and NATO Must Work Together; http://ec.europa.eu/research/fp7; www.nato.int/science.

${ }^{23}$ Currently there are 12 Nations as full SEDM members: Albania, Bosnia and Herzegovina, Bulgaria, Croatia, Greece, Italy, FYROM*, Romania, Slovenia, Turkey, Ukraine and USA (*Turkey recognizes Republic of Macedonia with its constitutional name).

${ }^{24}$ X24 Europe is a virtual on-line exercise that demonstrates the use of social media, crowdsourcing, and collaboration tools in an innovative, cost-effective, cloud-computing environment. It fosters the information-flow and coordination of activities by the international crisis-response community during the first 180 days of a natural disaster.

${ }^{25}$ Mario A. Laborie Iglesias, “NATO-EU Cooperation in the Atlantic Alliance’s Future Strategic Concept”, Real Instituto Elcano ARI no. 25 (April 2010). This English language version is available at www.realinstitutoelcano.org.

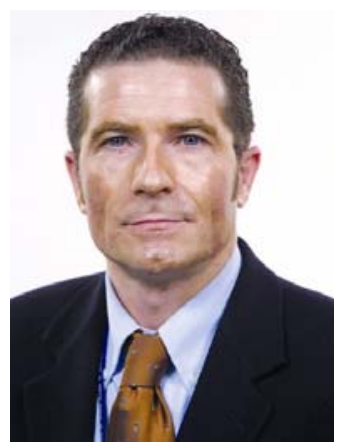

Cdr. Amleto GABELLONE was born in Taranto (IT) on July 21st 1963. He was awarded the electro-mechanical engineer master degree at the University of Pisa in 1989 and a master on underwater acoustic in 1993 at the Naval Academy in Livorno. Prior to his present appointment at NATO C3 Agency, he was Deputy Director of Naval Institute for Telecommunications and Electronics. From 2003 to 2006 he was Principal Scientist in Expeditionary MCM and Port Protection Thrust Area of NATO Undersea Research Centre. Cdr. Gabellone was technical officer on board major ITNA ships (1989-91 and 1994-96), teacher in the Electronics Group at the ITNA Petty Officer School (1991 - 1992) and head of Mine Warfare Weapon System and

Testing Ranges Department at the MCM Forces Command in La Spezia until 2003. Cdr. Gabellone has been national coordinator of IAP1 Captech (Components) for the European Defence Agency and national representative for NATO RTO SCI-211 Panel on Maritime Situational Awareness. He was associate professor at the Naval Academy from 1998 to 2009. Cdr. Gabellone is married with Angela and has two sons, Andrea and Alessandro.

E-mail: Amleto.Gabellone@nc3a.nato.int 